\title{
RECENT DEVELOPMENTS IN EUROPEAN COMPANY LAW: A WAY FORWARD TO MORE SOCIAL EUROPE?
}

\author{
Hana Horak * \\ Kristijan Poljanec ${ }^{* *}$
}

\begin{abstract}
Developments in EU Company Law show how EU Company Law has become more than just a set of market-driven rules focusing on overcoming legal barriers in cross-border investment. Non-binding guidelines on methodology for reporting non-financial information, combating discrimination on the grounds of gender by implementing the principle of equal treatment of men and women in matters of employment, proposal for a new legislation aiming at attaining a $40 \%$ objective of the under-represented sex in non-executive board-member positions in publicly listed companies are some of those initiatives. Several EU reports have stressed the positive impact of employee participation on companies' economic results, motivation and retention of employees. It is encouraging for stakeholders and the future of 'Social Europe' to see that the present European Company Mobility Package - tackling cross border conversions, mergers and divisions - takes an approach in favor of shareholders, employees and creditors. According to the European Economic and Social Committee, the new company law rules should make it easier for companies to merge, divide or move within the Single Market. New rules should ensure better protection of employees' rights and prevention of tax abuse. One may pose a question should the EU implement its social policies through EU Company Law. If so, which areas of EU Company Law should preserve (and enhance) social values? Could too much care for sustainability of social values eventually lead to non - sustainability of traditional company law?
\end{abstract}

\footnotetext{
Professor at Law Department, Faculty of Economics and Business, University of Zagreb; hhorak@efzg.hr

** Teaching and Research Assistant, Law Department, Faculty of Economics and Business, University of Zagreb; kpoljanec@efzg.hr
} 
KEYWORDS: EU Company Law, European Company Mobility Package, 'Social Europe', sustainability

\section{INTRODUCTION}

The last financial crisis has shown that one can no longer see companies as pure economic entities, de-contextualized from their social surrounding. Hegemonic "shareholder model" had passed through crisis. ${ }^{1}$ The time has come to look for an alternative model to the shareholder value model. ${ }^{2}$ Alternative model means, the one which will take into consideration the existence of internal stakeholders (shareholders and employees) and external stakeholders (creditors, clients, local community, state, etc.). ${ }^{3}$

If a company not pure economic entity, then one cannot see company law as purely internally oriented either. Namely, in many jurisdictions company law is seen as "supporting shareholder primacy drive" since it regulates the relationship between shareholders, the board and management. ${ }^{4}$ New age company law should refer to social objectives as well and open itself to broader social context. It calls for adoption of stakeholder model. ${ }^{5}$

The stakeholder model is the guiding principle of modern progress of corporate governance, which manifests itself in the model of so-called "sustainable company". ${ }^{6}$ As opposite to shareholder model, it takes into concern sustainability, involvement of stakeholders (in particular employees) into decision making

1 Vitols, S.; Kluge, N.: Introduction, in: Vitols, S.; Kluge, N. (eds.), The Sustainable Company: a new approach to corporate governance, Vol. I, Brussels, ETUI, 2012, p. 7.

2 Shareholder value model presupposes that social relations are set of contractual obligations and mechanisms to resolve conflicts and reduce uncertainty. Shareholders are key factor among different factors of production. This model was firm in the 1980's and the beginning of 2000s. Vitols, S., What is the Sustainable Company, in: Vitols, S.; Kluge, N. (eds.), The Sustainable Company: a new approach to corporate governance, Vol. I, Brussels, ETUI, 2012, pp. 15-16. The shareholder concept gives priority to the shareholders in corporate governance and increasing of shareholders' wealth is considered to be the primary function of a company. See Vitols, S.; Heuschmid, J., Introduction, in Vitols, S., Heuschmid, J. (eds.), European Company Law and the Sustainable Company: a stakeholder approach, Vol. II, Brussels, ETUI, 2013, p. 9.

3 Ibid., p. 13.

4 Sjåfjell, B., Regulating companies as if the world matters, in Vitols, S., Heuschmid, J. (eds.), European Company Law and the Sustainable Company: a stakeholder approach, Vol. II, Brussels, ETUI, 2013, p. 270.

5 Stakeholder theory recognizes that a company is a social organization dependent on different groups: employees, suppliers, investors, community etc. Vitols, op. cit. (ref. 2), p. 15.

$6 \quad$ Ibid., p. 24. 
process, ${ }^{7}$ transparency in reporting financial and non-financial information, dependence of executive remuneration to achievement of sustainability goals and long term "socially conscious" investments. As will be elaborated below, these principles comply well with previous and recent EU legal initiatives. ${ }^{8}$

A good example of conceptual shift from isolated company law to "socially engaged" company law has its traces in the field of labor law. Board - level employee representation has been a common element of major EU company law initiatives. ${ }^{9}$ Any legal initiative in the field of company law calls for implementation of holistic approach that takes into concern both labor law elements and company law elements. I.e. company law should not be isolated from other legal fields. ${ }^{10}$ Although labor law and company law are different legal areas by their subject matter and aims, ${ }^{11}$ two fields intertwine since social sphere impacts economic sphere and vice versa. ${ }^{12}$ Holistic, socio-economic approach to company law requires that law making processes embed company law, tax law, capital markets law and labor law as mutually intertwined elements of a company law framework. ${ }^{13}$

Empirical proof of positive effects of such approach one can notice in initiatives regarding European company law. Those legal initiatives, which have integrated company law and labor law elements, have shown successful. On the other hand, those initiatives that have drawn a clear (or formalistic?) line between two legal fields simply failed. ${ }^{14}$

Indeed, employee participation is an example of how social policy issues have eventually become EU company law issues. Employee share ownership (ESO), in particular its individual share ownership as part of employee financial ownership (EFO) in the nineties had been predominantly regarded as related so-

7 E.g. board level employee participation, European Works Council, collective bargaining. Ibid.

8 Such change of paradigm reflects its twin brother Anglo-American concept of "progressive corporate law". Conchon, A., Regulating company law: the need for a holistic approach, in: Vitols, S., Heuschmid, J. (eds.) European Company Law and the Sustainable Company: a stakeholder approach, Vol. II, Brussels, ETUI, 2013, p. 75, note 8.

9 Ibid., p.71.

$10 \quad$ Ibid., p.72.

11 Labor law traditionally focuses on social aims (protection of a priori economically weaker party) and company law is traditionally business-oriented, dealing with relations between a company, managers and shareholders.

12 Conchon, op. cit. (ref. 8), p.74. E.g., Statute on Societas Europea took into concern employee participation, as well as legislation on Societas Cooperative Europea.

13 Conchon, op. cit. (ref. 8), p.75.

14 Ibid., p.80. 
cial policy. ${ }^{15}$ New way of thinking about ESO/EFO has begun with Action Plan to Reform EU Company Law and Corporate Governance in 2012. The ESO stands for the "element that ought to be considered in the design of any well-functioning governance framework. "16

When speaking of fundamental social values of the European Union ${ }^{17}$ we mean not only those embedded in EU primary law - European Union Treaties ${ }^{18}$ and the Charter of Fundamental Rights of the EU. ${ }^{19}$ We mean also the European Convention on Human Rights. ${ }^{20}$ Namely, fundamental rights, as guaranteed by the European Convention for the Protection of Human Rights and Fundamental Freedoms, as they result from the constitutional traditions common to the Member States, constitute general principles of EU law. ${ }^{21}$ Analysis of these documents has shown how "social" and "economic" are often mentioned together in EU fundamental documents. ${ }^{22}$ One can feel the idea of balance between "social" and "economic" behind.

15 The Promotion of Employee Ownership and Participation, Study prepared by the Inter-University Centre for European Commission's DG Markt (Contract MARKT/2013/0191F2/ST/ OP), Final report October 2014, p. 17. [http://ec.europa.eu/internal_market/company/docs/ modern/141028-study-for-dg-markt_en.pdf ], accessed on 9/5/2018.

16 Communication from the Commission to the European Parliament, the Council, the European Economic and Social Committee and the Committee of the Regions, Action Plan: European company law and corporate governance - a modern legal framework for more engaged shareholders and sustainable companies, COM/2012/0740 final. Hereinafter as: Action Plan...

17 Hereinafter as: EU.

18 See e.g. Preamble of the Treaty on European Union, consolidated version, (OJ C 202, 7/6/2016), p. 13-388 (hereinafter as TEU). See also Art. 3 (3) TEU; Protocol No. 28 attached to TEU; Art. 21 (2)(d) TEU. See Preamble of the Treaty on the Functioning of the EU, consolidated version, (OJ C 202, 7/6/2016), p. 1-388 (hereinafter as TFEU). See also Art. 4 TFEU, Art. 5 TFEU; Art. 9 TFEU; Art. 21 TFEU; Art 107 TFEU, Title X TFEU etc.

19 See Preamble of the Charter of Fundamental Rights of the EU, (OJ C 202, 7/6/2016), p. 389-405 (hereinafter as CFREU). See also Art. 34 CFREU; Art. 36 CFREU.

20 The Convention for the Protection of Human Rights and Fundamental Freedoms, as amended by Protocols Nos. 11 and 14 supplemented by Protocols Nos. 1, 4, 6, 7, 12 and 13, [http://www.echr.coe.int/Documents/Convention_ENG.pdf ], accessed on 8/5/2018.

21 Art. 6 (3) TEU.

22 E.g. TEU's preamble says how Member States were „determined to promote economic and social progress for their peoples, taking into account the principle of sustainable development and within the context of the accomplishment of the internal market and of reinforced cohesion and environmental protection, and to implement policies ensuring that advances in economic integration are accompanied by parallel progress in other fields (...). Art 3(3) TEU says the Internal Market „shall work for the sustainable development of Europe based on balanced economic growth and price stability, a highly competitive social market economy, aiming at full employment and social progress. (...) It shall combat social exclusion and discrimination, and shall promote social justice and protection, equality between women and men, (...). 
Numbers of recent EU documents promote social values as part of EU's long term perspective. If we just have a look at the Europe 2020 Strategy, we can see how it tackles several priorities: smart and sustainable growth, job creation and poverty reduction. ${ }^{23}$ Such state of art leads to the conclusion: "social" and "economic" are intertwined, complementary aspects of the Internal Market. In another words, EU social model is deeply integrated into EU economy. Socio-economic, or in Conchon's words, holistic approach is straightforwardly integrated into EU law.

In the next chapter, we will try to prove how contemporary EU Company Law tends to be more social and less market-driven. In third chapter we are focusing on the question should EU Company Law implement its social objectives through company law. In concluding remarks, we have summarized some of our main points.

\section{MORE SOCIAL AND LESS MARKET DRIVEN COMPANY LAW}

Recent developments and legislative initiatives in the area of EU Company Law and Corporate Governance show that this area has become more than just a set of market-driven rules focusing on overcoming legal barriers in cross-border investment. To name just a few: interconnection of business ${ }^{24}$ and insolvency registers $^{25}$ as instruments for increasing pan-EU transparency and enabling potential creditors (including workers) to react promptly in order to save their claims. Revised Directive on Shareholders' Rights has provided even higher

\footnotetext{
“TFEU's preamble says how Member States were „resolved to ensure the economic and social progress of their States by common action to eliminate the barriers which divide Europe (...). “ Art. 151 how ,the Union and the Member States, having in mind fundamental social rights such as those set out in the European Social Charter signed at Turin on 18 October 1961 and in the 1989 Community Charter of the Fundamental Social Rights of Workers, shall have as their objectives (...) dialogue between management and labor (...).“

23 See [http://ec.europa.eu/europe2020/europe-2020-in-a-nutshell/priorities/index_en.htm], accessed on $8 / 5 / 2018$.

24 Directive 2012/17/EU of the European Parliament and of the Council of 13 June 2012 amending Council Directive 89/666/EEC and Directives 2005/56/EC and 2009/101/EC of the European Parliament and of the Council as regards the interconnection of central, commercial and companies registers Text with EEA relevance, (OJ L 156, 16/6/2012), p. 1-9. For more details on this topic refer to Horak, H.; Dumančić, K., Poljanec, K.: The Interconnection of Company Data - a Way Forward in Development of Freedom of Establishment?, European Journal of Economics and Management, 3(1), 2016, pp. 134-152, [http://search.proquest.com/ openview/5b16e74fbc3cb696b3d631acbb0a81ed/1.pdf?pq-origsite=gscholar\&cbl=2035019], accessed on 14/5/2018.
}

25 [https://e-justice.europa.eu/content_insolvency_registers-110-en.do], accessed on 8/5/2018. 
protection of shareholders than it has been the case before. It aims at stimulating long-term engagement and increasing transparency. ${ }^{26}$ The Directive on Non-Financial Reporting ${ }^{27}$ has been a significant step towards making business accountable to society and it is a major success for the corporate accountability. Combating discrimination on the grounds of gender by implementing the principle of equal treatment of men and women in matters of employment, proposal for a new legislation aiming at attaining a $40 \%$ objective of the under-represented sex in non-executive board-member positions in publicly listed companies aim to accelerate progress towards a better gender balance on the boards of European companies. ${ }^{28}$ In December 2015 the Commission launched consultations which aim gathering information to which degree different actors in investment chains take $\mathrm{ESG}^{29}$ information into concern when investing. ${ }^{30}$ Seeking a positive social or environmental impact of investments is considered as one the main rationales behind ESG. ${ }^{31}$

Considering EU secondary law - directives and regulation- one may notice that development of EU company law shows two straightforward ideas: abolishment of impediments to cross-border doing business ${ }^{32}$ and the one which could be described as ,triple $\mathrm{p}^{\text {“: }}$ prevention, protection, publicity.

26 Directive 2017/828 of the European Parliament and of the Council amending Directive 2007/36/EC as regards the encouragement of long-term shareholder engagement (OJ L 132, 20/5/2017), p. $1-25$.

27 Directive 2013/34/EU of the European Parliament and of the Council of 26 June 2013 on the annual financial statements, consolidated financial statements and related reports of certain types of undertakings, amending Directive 2006/43/EC of the European Parliament and of the Council and repealing Council Directives 78/660/EEC and 83/349/EEC (Directive 2013/34/EU) (OJ L 182, 29/6/2013), p.19. Amended by Directive 2014/95/EU of the European Parliament and of the Council of 22 October 2014 amending Directive 2013/34/EU as regards disclosure of non-financial and diversity information by certain large undertakings and groups (Directive 2014/95/EU) (OJ L 330, 15/11/2014), p. 1-9 and Council Directive 2014/102/EU of 7 November 2014 adapting Directive 2013/34/EU of the European Parliament and of the Council on the annual financial statements, consolidated financial statements and related reports of certain types of undertakings, by reason of the accession of the Republic of Croatia Text with EEA relevance, (OJ L 334, 21/11/2014), p. 86-87.

28 See Strategic Engagement for Gender Equality 2016-2019, p. 14, [http://ec.europa.eu/justice/gender-equality/document/files/strategic_engagement_en.pdf ], accessed on 9/5/2018.

29 Environmental, social and governance information.

30 Summary of the Responses to the Public Consultations on long-term and sustainable investment, Brussels, October 2016 JUST/A3, [http://ec.europa.eu/information_society/newsroom/ image/document/2016-44/feedback_final_pc_30068_en_19173.pdf.], accessed on 8/5/2018.

31 Summary, p. 6.

32 On freedom of establishment and related freedom of capital movements as fundamental freedoms aiming at enforcement of cross-border investments, see Horak, H.; Dumančić, K.; Poljanec, K., European Market Law: Textbook, Vol. I, Zagreb, University of Zagreb, Faculty of 


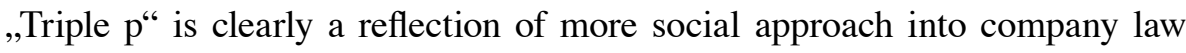
area. In another words, the EU has been trying to meet social policy objectives through secondary legislation. Through the years, the attempts to find a solution on EU level in favorem of freedom of establishment and the internal market have shown that half solutions and compromises simply cannot work in business practice. ${ }^{33}$ Alternatively, more accurately, some solutions cannot find their way to actual implementation due to the (future) 27 different company law systems.

There have been some new initiatives, which relate to some aspect of protecting fundamental social rights and integrating them into EU law. Social oriented policy is well embedded into the core of EU Company Law. In that regard, it is encouraging for all stakeholders and the future of Social Europe ${ }^{34}$ to see that the present European Company law package takes an approach in favorem of shareholders, employees and creditors, creating the much-needed legal security. Namely, in April 2018 the Commission launched so called 'European Company Mobility Package'. ${ }^{35}$ In two proposals,${ }^{36}$ one can notice furthering social approach when it comes to development of company law at supranational level. According to the European Economic and Social Committee, ${ }^{37}$ the new company law rules will make it easier for companies to merge, divide

Economics and Business, Zagreb, 2015, pp. 101-107 and pp. 120-141, [http://web.efzg.hr/dok/ KID//European\%20Market\%20Law\%20online.pdf.]

33 Vitols, S.: EU Company Mobility Package: Implications for Social Europe. Available at [https://www.socialeurope.eu/eu-company-mobility-package-implications-for-social-europe], accessed on 11/5/2018.

34 See [http://institutdelors.eu/publications/a-new-start-for-social-europe/?lang=en], accessed on 11/5/2018. This Report, commissioned by the Ministry of Labour, Employment and the Social and Solidarity Economy of Luxembourg, focuses on 'Why' a new start for Social Europe is necessary, and on 'How' a new start for Social Europe is feasible. It identifies three pillars on which the Social Europe project should be grounded:

${ }^{1)}$ an investment strategy in human capital which can set the basis for growth and competitiveness based on social inclusion and resilience;

${ }^{2)}$ an enhanced and fairer labour mobility across EU member states to build a truly European labour market;

3) a pro-convergence reform of the European economic governance that can reconcile social and macroeconomic objectives.

35 See more [https://ec.europa.eu/info/publications/company-law-package_en ], accessed on $16 / 7 / 2018$.

36 Proposal for a Directive of the European Parliament and of the Council amending Directive (EU) 2017/1132 as regards cross-border conversions, mergers and divisions COM/2018/241 final - 2018/0114 (COD) (hereinafter as: Proposal, Cross-border...) and Proposal for a Directive of the European Parliament and of the Council amending Directive (EU) 2017/1132 as regards the use of digital tools and processes in company law Com/2018/239 Final - 2018/0113 (COD).

37 See [https://www.eesc.europa.eu/en/tags/company-law], accessed on 16/7/2018. 
or move within the Single Market. In addition, the new rules will ensure that employees' rights are well protected and tax abuse is prevented. So maybe it is new path, as some author's note, ${ }^{38}$ for building social business in Europe?

The answer should be in affirmative. In August 2018, the EU Parliament has issued the draft report on proposal of amendment of EU legislation in the area of cross-border conversions, mergers and divisions. ${ }^{39}$ The EU Parliament confirmed the necessity of strong safeguards and proper protection for stakeholders (creditors, employees, shareholders). ${ }^{40}$ Particular emphasis is on protection of workers. ${ }^{41}$ Even stronger accent is on employee participation, employees' information and consultation rights. ${ }^{42}$ Thus, one can notice the trend of furthering the idea of building social business in Europe. ${ }^{43}$

In methodological terms, the EU is trying to enforce ex ante approach when dealing with company law and corporate governance issues. By asking for more equality, more disclosure and transparency, more diversity and more representation, it in fact aims at preventing problems before they actually occur. At the same moment, EU law protects vulnerable social groups from being underrepresented and thus socially marginalized (protective element) or cheated by those who hold stronger position in asymmetric social relations (publicity element). This way the EU has introduced a sort of "joint responsibility" of

38 Möslein, F.: Building Social Business in Europe, European Company Law, 12(6), 2015, pp. $268-269$.

39 See DRAFT REPORT on the proposal for a directive of the European Parliament and of the Council amending Directive (EU) 2017/1132 as regards cross-border conversions, mergers and divisions ( COM(2018)0241 - C8-0167/2018 - 2018/0114(COD)), [http://www.europarl. europa.eu/meetdocs/2014_2019/plmrep/COMMITTEES/JURI/PR/2018/09-03/1161004EN. pdf], accessed on 9/10/2018. Hereinafter as: EP Draft Report.

40 See in particular EP Draft Report, Amendment 1; EP Draft Report, Amendment 3, EP Draft Report, Amendment 23,; EP Draft Report, Amendment 49. see also Explanatory Statement, EP Draft Report, p. 88.

41 See EP Draft Report, Amendment 2,

42 See (in cogent manner) in particular the following amendments: EP Draft Report, Amendment 5,; EP Draft Report, Amendment 9,; EP Draft Report, Amendment 10,; EP Draft Report, Amendment 11,; EP Draft Report, Amendment 15; EP Draft Report, Amendment 16; EP Draft Report, Amendment 18; EP Draft Report, Amendment 20; EP Draft Report, Amendment 48; EP Draft Report, Amendment 59; EP Draft Report, Amendment 64; EP Draft Report, Amendment 65; EP Draft Report, Amendment 66; EP Draft Report, Amendment 68; EP Draft Report, Amendment 88; EP Draft Report, Amendment 119.

43 As it has been well put by the EU Parliament: " Employees are the most worth protecting stakeholders. They have a genuine interest of sustainability and long-term success of the companies as their jobs depend on the companies' success. In the light of the European Pillar of Social Rights, laws must upheld and strengthen the position and protection of workers and employees”. See EP Draft Report, p. 88; see also EP Draft Report, pp. 89-90. 
the EU, the Member States and private actors - companies - for solving social issues. A state is not anymore sole responsible for social stability. Public and private factors have somehow split this task among themselves.

\section{IMPLEMENTATION OF EU SOCIAL POLICIES VIA COMPANY LAW?}

As company lawyers, we feel slight skepticism towards the idea of using company law and corporate governance as tools for achieving social aims. Yet, EU Company Law has "EU" attribution, which implies above-mentioned socio-economic component of EU law.

Recent trends are not result of some short-term idealistic viewpoint of the Commission. Even if we look purely formalistically, those trends are deeply rooted into EU's fundamental law. I.e. they have been approved by Member States themselves. Firm standpoint of the EU as social market economy was emphasized in Juncker's State of the Union 2016 speech and has marked his mandate. ${ }^{44}$

As consequence of the financial crisis, the way companies are governed is not considered only through economic lens. This paper has already stressed how pure shareholder-based thinking had a role in the problems that the EU faced. ${ }^{45}$ Public and private interests are not (as it sometimes might seem) necessarily opposed. By developing shareholders' rights, market abuse prevention, employee participation, interconnection of business registers, transparency and disclosure requirements, EU Company Law and Corporate Governance contribute both to company's sustainability and public interests in general. Furthermore, efficient functioning of corporate governance and implementation of company law norms, as well as maintaining control guarantee efficient functioning of capital markets. This will eventually lead to attracting investments, higher economic growth and employment rate. Again, a company will benefit. The financial crisis taught us how non transparent operations under weak corporate governance can affect not only the company itself but the entire economy, ${ }^{46}$ even on the global level.

\footnotetext{
44 See [http://europa.eu/rapid/press-release_IP-16-3042_en.htm], accessed on 9/5/2017.

45 Mähönen, J.: Law and Economics in European Company Law, Working Paper Annual Legal Research Network, 2009., p. 3, [https://www.researchgate.net/publication/242174162_ Law_and_Economics_in_European_Company_Law], accessed on 29/4/2018; Vives, A., Corporate Social Responsibility: The Role of Law and Markets and the Case of Developing Countries', Chi.-Kent.L.Rev., 199(83), 2008, p. 207., [http://scholarship.kentlaw.iit.edu/cklawreview/vol83/iss1/12], accessed on 16/7/2018.

46 About the relationship between these factors see more in Hopt, K.; Wymeersch, E.; Kanda, H.; Baum, H. Corporate Governance in Context: Corporations, States and Markets in Europe, Japan and the US, Oxford, 2005.
} 
The classical definition of the corporate governance includes the relationship between shareholders, creditors and corporations; between financial markets, institutions and corporations; and between employees and corporations. ${ }^{47}$ In another words, corporate governance integrates both "social" element and "corporate" element. It is also a field in which artificial division among "corporate" and "social" seems futile. As Hopt expressed it metaphorically, this field is today one of the most active melting pots of economic, legal and social sciences research ${ }^{48}$ Companies are becoming socially responsible when they consider social, environmental, ethical, consumer and human rights concerns as part of business strategy and operations.

Issue of Corporate Social Responsibility (CSR) is also important for the sake of a company. In the ambit of EU law, the EU Directive on Non-Financial Reporting is an example and significant step towards making business accountable to society and it is major success for the corporate accountability. This Directive enhances transparency through obligatory disclosure of human rights policy, social and environmental risks in largest companies on the EU market because that information have the same impact as a disclosure of financial information. Management over a company tackles company's duties towards stakeholders in social, financial and ecological areas. Salaries policy, rewards and bonuses for managers stand in close relation to financial, social and ecological performances and correlate to social expectations of just and sound remuneration policy. That is exactly the reflection of the equilibristic idea of the founding treaties. As Vitols nicely pointed out "the growing interest in CSR is also a reflection of the recognition that shareholder value does not address social and environmental needs. ${ }^{49}$

In spite of affirmative viewpoint on infiltration of public interest into EU Company Law, some sort of balance between "social" and "economic" should be kept. Let us take one example.

\footnotetext{
47 Classens, S.; Yurtoglu, B., Corporate governance in emerging markets: A Survey, 2012, p. 4, [http://ssrn.com/abstract=1988880], accessed on 16/7/2018. One of the most used definitions of corporate governance is one given in OECD Principles of Corporate Governance first realized in 1998 and last time revised in November 2015. Available at [http://www.oecd. org/corporate/principles-corporate-governance.htm.], accessed on 16/7/2018. For other definitions see also Shleifer, A.; Vishny, R. W., A Survey of Corporate Governance, The Journal of Finance, 52(2), pp. 737-783, [http://www.jstor.org/stable/2329497], accessed on 16/7/2018. See also Hopt, K. J.; Leyens, P.C., Board models in Europe. Recent developments of Internal Corporate Governance Structures in Germany, the United Kingdom, France and Italy, Law working paper no. 18, 2004, p. 3, [http://ssrn.com/abstract=487944], accessed on 16/7/2018.

48 Hopt, K. J.: Comparative Company Law, in: Reimann, M.; Zimmerman, R. (eds.), The Oxford Handbook of Comparative Law, Oxford, Oxford University Press, 2008, p. 1187.

49 Vitols; Kluge, op. cit. (ref. 1), p. 20.
} 
Revised Shareholder's Directive introduced right of shareholders to cast binding or advisory vote on the remuneration policy of the directors of their company. ${ }^{50}$ It is a clear tendency to grant additional shareholders' rights and result of contemporary tendencies around the world, which fight for enhancing shareholders rights. ${ }^{51}$ Revitalization of private shareholders rights by granting them more rights (and facilitating their use at the same moment) is a modern tendency ${ }^{52}$ Nevertheless, this might show tricky as Swiss example shows.

In 2013 Swiss voters decided to introduce binding say-on-pay for shareholders of all publicly traded firms. The result was positive and referendum outcome was implemented into constitutional amendment. Although such public, direct democratic procedure has led to empowerment of shareholders, it in fact shaped investors' rights and interfered with, from the private law perspective, internal matters of Swiss companies. However, the fear of those same shareholders was that the directors might hold up - the directors' might feel reluctant to invest more incentive into decision -making. That may lead to lower firm value. As Wagner and Wenk ${ }^{53}$ noted "while the idea of shareholder power may appeal to the public as a control mechanism, shareholders themselves may feel that less can be more when it comes to shareholders rights. Shareholder power reduces agency costs, but accentuates hold up problems."

Since revised Shareholders' Rights Directive leaves it for the Member States to enable binding and advisory say-on-pay, one should consider the consequences of such solution. Although shareholders believe that binding say-on-pay brings benefits, such model can affect negatively on managerial incentives. ${ }^{54}$ Paradoxically, maintaining status quo concerning shareholder power might be better solution for shareholders than to maximize their powers. ${ }^{55}$ In another words, shareholder democracy should not contravene shareholder's best interests. Moreover, any legislative proposals should take into concern economic implications of direct societal interference. As Wagner and Wenk ${ }^{56}$ pointed out, tension within companies and companies and society should be mitigated. ${ }^{57}$

\footnotetext{
$50 \quad$ Revised Shareholders' Rights Directive, recital 29.

${ }_{51}$ Wagner, A. F.; Wenk, C., Agency versus Hold-Up: Benefits and Costs of Shareholder Rights, Financial Working Paper, No. 500, 2017, p. 31, [http://ssrn.com/abstract_id=1793089], accessed on 12/5/2018.

52 Hopt, op. cit. (ref. 48), p. 1186.

53 Wagner; Wenk, op. cit. (ref. 51), p. 9.

54 Ibid.

55 Wagner; Wenk, op. cit. (ref. 51), p. 36.

56 Wagner; Wenk, op. cit. (ref. 51), p. 32.

57 Mitigation of social tension at legislative level one can notice by refering to cross-border conversion. The protection of workers' rights in light of new proposal on cross-boder con-
} 
From the legal perspective, private and public law rules should ensure effective regulatory framework. From the corporate governance perspective, beside the hard law rules, the self-discipline within a company and board can been achieved through the set of soft law rules.

There is a need for modern set of binding rules bearing in mind that soft-law rules $^{58}$ in the form of recommendations haven't efficiently achieved certain goals. On the other hand, it must be born in mind that mandatory rules can reduce the focus on the substance of good governance and they can remove the key responsibility of boards and shareholders for the quality of corporate governance and reduce the governance to the compliance debate with the regulators. Formalistic "comply or explain" 59 approach leads to a legalistic board approach with no in-depth board discussion on the governance of firm but with lawyers and auditors that have to fulfill necessary formalities. ${ }^{60}$ Again, introduction of rules urges for a balance between hard law and soft law solutions.

From the above considerations, we can conclude that corporate governance; in particular, CSR, as well as employee participation will continue to stand for key areas of EU Company Law in terms of further promotion of social objectives. ${ }^{61}$ Previous experience has shown that it can be achieved via hard law approach as well. In fact, hard law instruments incorporating social note have shown to be more successful initiatives than mainstream company law proposals.

versions shows that social approach has been in focus of that regulation. See rec. 4 Proposal, Cross-border...

58 About soft law see more in Bodiroga Vukobrat, N.; Horak, H.: Corporate Governance Codes - an instrument of the social responsible governance, in: Socially Responsible Governance, Collection of Papers, Zagreb, 2008., p. 201. See also Wymeersch, E.: Implementation of the Corporate governance Codes, in: Hopt, K; Wymeersch, E.; Kanda, H.; Baum, H., Corporate Governance in Context: Corporations, States and Markets in Europe, Japan and the US, Oxford, 2005.

59 See more about "comply and explain" principle and the role of the corporate governance codes in Horak, H.; Bodiroga-Vukobrat, N.: EU Member States' Experiences with the „Comply or explain" Principle in Corporate Governance, Croatian Yearbook of European Law and Policy, 7(7), Zagreb, 2011, pp. 179-200. See also Seidl, D.; Sanderson P., Applying „Comply or explain": conformance with codes of corporate governance in the UK and Germany, Centre for Business Research, University of Cambridge Working Paper No. 389 , 2009, p. 5., [http:// www.cbr.cam.ac.uk/pdf/WP389.pdf ], accessed on 14/5/2018.

60 EcoDa „Comply or explain“, Preserving governance flexibility with quality explanations, Report, EcoDa Annual Conference, 2012, p. 7., [http://www.ecoda.org/docs\%20-\%20OK/Conferences/2012_03_27\%20Comply\%20or\%20Explain/2012AnnualConf-ecoDa-CoEreport. pdf], accessed on 14/5/2017.

${ }_{61}$ According to Hopt, the pros and cons of labor cp-determination will be one of the areas of future economic and legal research in the core comparative company law. See Hopt, op. cit. (ref. 48), p. 1187. 


\section{CONCLUSION}

Last financial crisis revealed shortcomings of the model focusing solely on shareholders as key factors in corporate governance schemes. Trends in revisiting EU Company Law show shift from purely market-driven concept of company law to the stakeholder model of sustainable company. Clear call for more disclosure, more stimulation of institutionalized employee engagement and long -term investments, more care for gender diversity, as well as stronger control over directors' remuneration are some of the indicators of that shift. Such shift recognizes deep integration of European social model into Company Law. In the ambit of EU Company Law such shift has firm fundaments in primary and secondary law, with tendency to move forward towards even more holistic, integrative approach.

It is too early to predict how effective EU Company Mobility Package will be. We should wait and see implementation in practice. Some parts of this package stress the need to comply with objectives of European integration such as social protection (in particular the protection of workers). Inclusion of societal objectives into EU Company Law seems necessary for further development of EU Company Law and the EU should continue to include them into its legal corpus. In another words, sustainability of social values will eventually lead to sustainability of company law. In this context, CSR and employee participation seem to be an apt legal niche for further integration of social elements. Not only by means of soft law instruments but hard ones too.

Nevertheless, the EU still has not reached its paramount when it comes to achievement of social values through its law. It is obvious that ongoing work on CSR schemes and company law is going to continue with implementing social policy. Pending "Women on Boards" and "Working Parents and Caregivers" initiatives prove such thesis.

EU company law has been developing within EU social model. Even countries that are most immune to strict social models had to reconsider their positions and loosen their viewpoints. Artificial social de-contextualization of a company is not possible and certain level of infiltration of social interests is indispensable element of contemporary and future EU company law and corporate governance. Without integrative, socio-economic model of EU company law, company law will become poorer. As failed legislative initiatives of the Commission have shown, artificial division among labor law and pure, mainstream company law bring no good to further development of EU Company Law. EU Company law without its social component will be stuck in a deadlock. 


\section{LITERATURE}

1. Bodiroga Vukobrat, N.; Horak, H.: Corporate Governance Codes - an instrument of the social responsible governance, in: Socially Responsible Governance, Collection of Papers, Zagreb, 2008

2. Classens, S.; Yurtoglu, B., Corporate governance in emerging markets: A Survey, 2012, [http://ssrn.com/abstract=1988880], accessed on 16/7/2018

3. Conchon, A., Regulating company law: the need for a holistic approach, in: Vitols, S., Heuschmid, J. (eds.) European Company Law and the Sustainable Company: a stakeholder approach, Vol. II, Brussels, ETUI, 2013

4. Draft Report on the proposal for a directive of the European Parliament and of the Council amending Directive (EU) 2017/1132 as regards cross-border conversions, mergers and divisions ( COM(2018)0241 - C8-0167/2018 - 2018/0114(COD)), [http://www.europarl.europa.eu/meetdocs/2014_2019/plmrep/COMMITTEES/ JURI/PR/2018/09-03/1161004EN.pdf], accessed on 9/10/2018 .

5. EcoDa „Comply or explain“, Preserving governance flexibility with quality explanations, Report, EcoDa Annual Conference, 2012, [http://www.ecoda. org/docs\%20-\%20OK/Conferences/2012_03_27\%20Comply\%20or\%20Explain/2012AnnualConf-ecoDa-CoEreport.pdf], accessed on 14/5/2017.

6. Hopt, K. J.: Comparative Company Law, in: Reimann, M.; Zimmerman, R. (eds.), The Oxford Handbook of Comparative Law, Oxford, Oxford University Press, 2008

7. Hopt, K. J.; Leyens, P.C., Board models in Europe. Recent developments of Internal Corporate Governance Structures in Germany, the United Kingdom, France and Italy, Law working paper no. 18, 2004, [http://ssrn.com/abstract=487944], accessed on 16/7/2018

8. Hopt, K.; Wymeersch, E.; Kanda, H.; Baum, H. Corporate Governance in Context: Corporations, States and Markets in Europe, Japan and the US, Oxford, 2005.

9. Horak, H.; Bodiroga-Vukobrat, N.: EU Member States' Experiences with the „Comply or explain" Principle in Corporate Governance, Croatian Yearbook of European Law and Policy, 7(7), Zagreb, 2011

10. Horak, H.; Dumančić, K.; Poljanec, K., European Market Law: Textbook, Vol. I, Zagreb, University of Zagreb, Faculty of Economics and Business, Zagreb, 2015, [http://web.efzg.hr/dok/KID//European\%20Market\%20Law\%20online.pdf.]

11. Horak, H.; Dumančić, K., Poljanec, K.: The Interconnection of Company Data - a Way Forward in Development of Freedom of Establishment?, European Journal of Economics and Management, 3(1), 2016, [http://search.proquest.com/ openview/5b16e74fbc3cb696b3d631acbb0a81ed/1.pdf?pq-origsite=gscholar\&cbl=2035019], accessed on 14/5/2018. 
12. Mähönen, J.: Law and Economics in European Company Law, Working Paper Annual Legal Research Network, 2009., p. 3, [https://www.researchgate.net/ publication/242174162_Law_and_Economics_in_European_Company_Law], accessed on $29 / 4 / 2018$

13. Möslein, F.: Building Social Business in Europe, European Company Law, 12(6), 2015

14. Seidl, D.; Sanderson P., Applying „Comply or explain“: conformance with codes of corporate governance in the UK and Germany, Centre for Business Research, University of Cambridge Working Paper No. 389, 2009, [http://www.cbr.cam. ac.uk/pdf/WP389.pdf ], accessed on 14/5/2018.

15. Shleifer, A.; Vishny, R. W., A Survey of Corporate Governance, The Journal of Finance, 52(2), [http://www.jstor.org/stable/2329497], accessed on 16/7/2018

16. Sjåfjell, B., Regulating companies as if the world matters, in Vitols, S., Heuschmid, J. (eds.), European Company Law and the Sustainable Company: a stakeholder approach, Vol. II, Brussels, ETUI, 2013

17. Vitols, S., What is the Sustainable Company, in: Vitols, S.; Kluge, N. (eds.), The Sustainable Company: a new approach to corporate governance, Vol. I, Brussels, ETUI, 2012

18. Vitols, S.: EU Company Mobility Package: Implications for Social Europe. Available at [https://www.socialeurope.eu/eu-company-mobility-package-implications-for-social-europe], accessed on 11/5/2018.

19. Vitols, S.; Heuschmid, J., Introduction, in Vitols, S., Heuschmid, J. (eds.), European Company Law and the Sustainable Company: a stakeholder approach, Vol. II, Brussels, ETUI, 2013

20. Vitols, S.; Kluge, N.: Introduction, in: Vitols, S.; Kluge, N. (eds.), The Sustainable Company: a new approach to corporate governance, Vol. I, Brussels, ETUI, 2012

21. Vives, A., Corporate Social Responsibility: The Role of Law and Markets and the Case of Developing Countries', Chi.-Kent.L.Rev., 199(83), 2008, p. 207., [http:// scholarship.kentlaw.iit.edu/cklawreview/vol83/iss1/12], accessed on 16/7/2018.

22. Wagner, A. F.; Wenk, C., Agency versus Hold-Up: Benefits and Costs of Shareholder Rights, Financial Working Paper, No. 500, 2017, [http://ssrn.com/abstract_ $\mathrm{id}=1793089$ ], accessed on 12/5/2018

23. Wymeersch, E.: Implementation of the Corporate governance Codes, in: Hopt, K; Wymeersch, E.; Kanda, H.; Baum, H., Corporate Governance in Context: Corporations, States and Markets in Europe, Japan and the US, Oxford, 2005 


\section{LEGISLATION}

1. Charter of Fundamental Rights of the EU, (OJ C 202, 7/6/2016), p. 389-405.

2. Convention for the Protection of Human Rights and Fundamental Freedoms, as amended by Protocols Nos. 11 and 14 supplemented by Protocols Nos. 1, 4, 6, 7, 12 and 13, [http://www.echr.coe.int/Documents/Convention_ENG.pdf], accessed on $8 / 5 / 2018$

3. Directive 2012/17/EU of the European Parliament and of the Council of 13 June 2012 amending Council Directive 89/666/EEC and Directives 2005/56/EC and 2009/101/EC of the European Parliament and of the Council as regards the interconnection of central, commercial and companies registers Text with EEA relevance, (OJ L 156, 16/6/2012), p. 1-9.

4. Directive 2013/34/EU of the European Parliament and of the Council of 26 June 2013 on the annual financial statements, consolidated financial statements and related reports of certain types of undertakings, amending Directive 2006/43/EC of the European Parliament and of the Council and repealing Council Directives 78/660/EEC and 83/349/EEC (Directive 2013/34/EU) (OJ L 182, 29/6/2013), p.19. Amended by Directive 2014/95/EU of the European Parliament and of the Council of 22 October 2014 amending Directive 2013/34/EU as regards disclosure of non-financial and diversity information by certain large undertakings and groups (Directive 2014/95/EU) (OJ L 330, 15/11/2014), p. 1-9 and Council Directive 2014/102/EU of 7 November 2014 adapting Directive 2013/34/EU of the European Parliament and of the Council on the annual financial statements, consolidated financial statements and related reports of certain types of undertakings, by reason of the accession of the Republic of Croatia Text with EEA relevance, (OJ L $334,21 / 11 / 2014)$, p. 86-87.

5. Directive 2017/828 of the European Parliament and of the Council amending Directive 2007/36/EC as regards the encouragement of long-term shareholder engagement (OJ L 132, 20/5/2017), p. 1-25.

6. Treaty on European Union, consolidated version, (OJ C 202, 7/6/2016), p. 13-388

7. Treaty on the Functioning of the EU, consolidated version, (OJ C 202, 7/6/2016), p. $1-388$

\section{OTHER SOURCES}

1. Communication from the Commission to the European Parliament, the Council, the European Economic and Social Committee and the Committee of the Regions, Action Plan: European company law and corporate governance - a modern legal framework for more engaged shareholders and sustainable companies, COM/2012/0740 final

2. Proposal for a Directive of the European Parliament and of the Council amending Directive (EU) 2017/1132 as regards cross-border conversions, mergers and divisions COM/2018/241 final - 2018/0114 (COD) 
3. Proposal for a Directive of the European Parliament and of the Council amending Directive (EU) 2017/1132 as regards the use of digital tools and processes in company law Com/2018/239 Final - 2018/0113 (COD)

4. Strategic Engagement for Gender Equality 2016-2019, p. 14, [http://ec.europa.eu/ justice/gender-equality/document/files/strategic_engagement_en.pdf ], accessed on $9 / 5 / 2018$

5. Summary of the Responses to the Public Consultations on long-term and sustainable investment, Brussels, October 2016 JUST/A3, [http://ec.europa.eu/information_society/newsroom/image/document/2016-44/feedback_final_pc_30068_ en_19173.pdf.], accessed on 8/5/2018.

6. The Promotion of Employee Ownership and Participation, Study prepared by the Inter-University Centre for European Commission's DG Markt (Contract MARKT/2013/0191F2/ST/OP), Final report October 2014, [http://ec.europa.eu/ internal_market/company/docs/modern/141028-study-for-dg-markt_en.pdf], accessed on 9/5/2018.

\section{ONLINE SOURCES}

1. [http://ec.europa.eu/europe2020/europe-2020-in-a-nutshell/priorities/index en.htm], accessed on 8/5/2018

2. [http://europa.eu/rapid/press-release_IP-16-3042_en.htm], accessed on 9/5/2017.

3. [http://institutdelors.eu/publications/a-new-start-for-social-europe/?lang=en], accessed on 11/5/2018.

4. [https://ec.europa.eu/info/publications/company-law-package_en], accessed on 16/7/2018.

5. [https://e-justice.europa.eu/content_insolvency_registers-110-en.do], accessed on $8 / 5 / 2018$

6. [https://www.eesc.europa.eu/en/tags/company-law], accessed on 16/7/2018.

7. http://www.oecd.org/corporate/principles-corporate-governance.htm.], accessed on $16 / 7 / 2018$ 
